\title{
PREDIKSI FINANCIAL DISTRESS MELALUI ALTMAN Z-SCORE
}

\author{
Endah Tri Wahyuningtyas, Dian Permata Sari \\ Prodi Akuntansi, Universitas Nahdlatul Ulama Surabaya \\ e-mail: endahtri@unusa.ac.id, dianpermata491@student.unusa.ac.id
}

\begin{abstract}
Unstable economic development poses a threat to companies experiencing financial distress and even bankruptcy. This study aims to determine and analyze the predictions of the bankruptcy of companies listed on the Indonesia Stock Exchange. The model used in this study is the Altman Z-Score ratio as a tool to see how big the potential for company bankruptcy is. The data used in this study is secondary data in the form of financial statements of companies listed on the Indonesia Stock Exchange. The sample used is 42 wholesale and retail trade sub-sector companies listed on the Indonesia Stock Exchange for the period 2012 to 2016 with a sampling technique that is purposive sampling. The results of this study indicate that during the observation period, large trading companies that have a tendency to experience financial distress are PT Bintang Mitra Semestaraya Tbk. (BMSR), PT Kobexindo Tractors Tbk. (KOBX), PT Perdana Bangun Pusaka Tbk. (KONI) PT Lautan Luas Tbk. (LTLS) while in retail trading companies there are no companies that have the potential to experience financial distress.
\end{abstract}

Keywords: altman Z-Score, financial distress, bankruptcy

\section{PENDAHULUAN}

Globalisasi ekonomi dan perkembangan teknologi yang kian pesat membuat persaingan usaha semakin ketat. Persaingan tersebut menuntut para pelaku usaha untuk terus melakukan inovasi produk, meningkatkan kinerja dan semakin memberi manfaat, serta kemudahan bagi pelanggan dalam menyelesaikan masalah-masalah yang mereka hadapi. Industri perdagangan besar dan eceran termasuk dalam kategori sub-sektor yang krusial bagi perekonomian Indonesia. Indikasi dari hal tersebut dapat kita lihat dari kontribusi sektor perdagangan terhadap total Produk Domestik Bruto (PDB) Indonesia. Perlu diingat bahwa total PDB Indonesia lebih banyak ditopang oleh aktivitas konsumsi, yang tentunya berkaitan erat dengan kinerja industri perdagangan eceran/ritel (Badan Pusat Statistik, 2017).

Perusahaan sektor perdagangan besar dan eceran akan terus berkembang di masa yang akan datang. Perkembangan inilah yang menye- babkan banyak bermunculan perusahaan-perusahaan baru di bidang industri perdagangan untuk bersaing. Ketidakmampuan perusahaan dalam mengantisipasi persaingan akan berakibat buruk, karena hal tersebut dapat memengaruhi eksistensi perusahaan yang apabila dibiarkan perusahaan akan mengalami financial distress yang dapat menyebabkan kebangkrutan (Rudianto, 2013).

Jika suatu perusahaan mengalami masalah dalam likuiditas maka sangat memungkinkan perusahaan tersebut mulai memasuki masa kesulitan keuangan (financial distress) dan jika kondisi kesulitan tersebut tidak cepat diatasi maka ini bisa berakibat kebangkrutan usaha (bankruptcy). Untuk menghindari kebangkrutan ini dibutuhkan berbagai kebijakan, strategi dan bantuan, baik bantuan dari pihak internal maupun eksternal.

Menurut Platt dan Platt (2002) financial distress merupakan suatu kondisi di mana keuangan perusahaan dalam keadaan tidak sehat 
atau mengalami krisis. Financial distress didefinisikan sebagai suatu kondisi di mana perusahaan mengalami kesulitan dalam memenuhi kewajibannya terhadap kreditor.

Salah satu metode yang dapat digunakan untuk memprediksi financial distress perusahaan adalah metode Altman Z-Score yang dikemukakan pertama kali oleh seorang profesor bisnis dari New York University AS Edward I. Altman pada tahun 1968. Metode ini mengombinasikan beberapa rasio keuangan yang terdapat dalam laporan keuangan menjadi model prediksi dengan teknik statistik.

Yulia Triyonowati (2013) menganalisis kebangkrutan perusahaan dengan metode Altman Z-Score pada perusahaan rokok go public. Hasil dari penelitian menyimpulkan bahwa terdapat 1 dari 3 perusahaan yang dinyatakan sehat, yaitu perusahaan PT Hanjaya Mandala Sampoerna Tbk. Yang dapat dilihat dari kemampuan perusahaan dalam meningkatkan kondisi keuangan dari tahun ke tahun.

Maina dan Sakwa (2017) meneliti financial distress pada perusahaan yang terdaftar di Bursa Efek Nairobi di Kenya. Teknik analisis yang digunakan yaitu Multi-Diskriminan Analisis (MDA) dengan menggunakan 30 sampel perusahaan yang terdaftar di NSE. Hasil dari penelitian tersebut menyimpulkan bahwa dari 30 perusahaan yang dianalisis hanya terdapat 5 perusahaan yang berada dalam zona non-distress.

Analisis kebangkrutan dan pengaruh harga saham pada perusahaan farmasi yang terdaftar di BEI dengan metode Altman Z-Score dengan menggunakan teknik analisis regresi linier sederhana yang dilakukan oleh Andriawan dan Salean (2016) menyimpulkan bahwa sebagian besar perusahaan manufaktur sektor farmasi di Bursa Efek Indonesia masuk dalam kategori perusahaan yang sehat.
Bagi para analis, laporan keuangan merupakan media yang paling penting untuk menilai prestasi dan kondisi ekonomis suatu perusahaan. Pada tahap pertama seorang analis tidak akan mampu melakukan pengamatan langsung ke suatu perusahaan, Seandainya dilakukan, ia pun tidak akan mengetahui banyak tentang situasi perusahaan. Laporan keuangan inilah yang menjadi bahan sarana informasi bagi seorang analis dalam proses pengambilan keputusan (Harahap, 2006).

Berdasarkan teori signalling bahwa laporan keuangan bermanfaat dalam memberikan informasi terkait kinerja keuangan dan non-keuangan perusahaan kepada pengguna laporan keuangan, sehingga dapat digunakan dalam memprediksi adanya potensi kebangkrutan (financial distress) di masa yang akan datang. Prediksi financial distress menjadi perhatian penting oleh berbagai pihak antara lain pemberi pinjaman, investor, pembuat peraturan, pemerintah, auditor, dan manajemen mengingat pentingnya persoalan kesulitan keuangan maka mendeteksi potensi kesulitan keuangan sejak awal akan sangat membantu bagi berbagai pihak untuk mengambil keputusan secara tetap.

Model prediksi financial distress Altman (1983) menemukan bahwa ada empat rasio yang dapat digunakan untuk mendeteksi kesehatan financial dan kebangkrutan sebuah perusahaan yaitu working capital to total asset, retained earning to total asset, earning before tax to total asset dan book value of equity to book value of total liabilities.

\section{METODOLOGI}

Jenis penelitian ini menggunakan metode kualitatif deskriptif dengan sumber data sekunder yaitu annual report periode 2012 hingga 2016. 
Sampel dalam penelitian ini menggunakan teknik purpose sampling yaitu teknik mengambil sampel dengan pertimbangan hal-hal tertentu yaitu (1) Perusahaan sub sektor perdagangan besar dan eceran yang terdaftar di Bursa Efek Indonesia; (2) Perusahaan sub sektor perdagangan besar dan eceran yang menerbitkan laporan keuangannya secara teratur pada tahun 2012 sampai dengan tahun 2016. Jadi total data penelitian sebanyak 42 perusahaan selama lima tahun.

Adapun rumus Altman Z-score (1995) sebagai berikut.

Z-score $=6,56 \mathrm{X} 1+3,26 \mathrm{X} 2+6,72 \mathrm{X} 3+$ $1,05 \mathrm{X} 4$

Di mana:

$\mathrm{X} 1=$ Rasio modal kerja terhadap total aktiva $\mathrm{X} 2$ = Rasio laba ditahan terhadap total aktiva $\mathrm{X} 3$ = Rasio EBIT terhadap total aktiva

$\mathrm{X} 4$ = Nilai pasar ekuitas terhadap nilai buku utang

Teknik analisis data yang dilakukan dalam penelitian ini pertama melakukan perhitungan rasio-rasio keuangan perusahaan sesuai dengan variabel model altman. Kemudian menghitung nilai Z-score dengan mengklasifikasikan kondisi perusahaan sesuai dengan standar yang telah ditentukan. Terakhir yaitu menyimpulkan perusahaan yang cenderung mengalami kondisi aman/ sehat, kondisi rawan/financial distress dan kondisi bangkrut selama periode 2012-2016 dengan menggunakan kriteria penilaian financial distress sebagai berikut.

Bila $Z>2,6=$ zona "aman"

Bila $1,1<Z<2,6$ = zona "abu-abu"

Bila $Z<1,1=$ zona "distress" berbahaya

Definisi operasional penelitian ini menggunakan rasio keuangan yang sesuai dengan metode Altman Z-score sebagai berikut.

\section{Working Capital to Total Asset $\left(\mathrm{X}_{1}\right)$}

Rasio ini untuk mengukur likuiditas dengan membandingkan aset likuid bersih dengan total aset. Aset likuid bersih atau modal kerja didefinisikan sebagai aset lancar dikurangi total kewajiban lancar (aset lancar - utang lancar).

$$
\text { Rasio } \mathrm{X}_{1}=\frac{\text { Modal Kerja }}{\text { Total Aset }}
$$

2. Retained Earning to Total Asset $\left(\mathrm{X}_{2}\right)$

Rasio ini merupakan rasio profitabilitas yang mendeteksi kemampuan perusahaan dalam menghasilkan keuntungan. Rasio ini mengukur besarnya kemampuan suatu perusahaan dalam memperoleh keuntungan.

$$
\mathrm{X}_{2}=\frac{\text { Laba Ditahan }}{\text { Total Aset }}
$$

3. Earning before Interest and Taxes to Total Asset $\left(\mathrm{X}_{3}\right)$

Rasio ini mengukur profitabilitas, yaitu tingkat pengembalian aset, yang dihitung dengan membagi laba sebelum bunga dan pajak (earning before interest and tax) tahunan perusahaan dengan total aset neraca akhir tahun. Rasio ini menjelaskan pentingnya pencapaian laba perusahaan terutama dalam rangka memenuhi kewajiban bunga para investor.

$\mathrm{X}_{3}=\frac{\mathrm{EBIT}}{\text { Total Aset }}$

4. Book Value of Equity/Book Value of Total Debt $\left(\mathrm{X}_{4}\right)$

Rasio ini merupakan kebalikan dari utang per modal sendiri (der debt to equity ratio). Nilai modal sendiri yang dimaksud adalah nilai pasar modal sendiri yaitu jumlah saham perusahaan dikaitkan dengan pasar saham per lembar saham perusahaan dikalikan dengan pasar saham per lembar sahamnya (jumlah lembar saham $\mathrm{x}$ harga pasar saham per lembar).

$X_{4}=\frac{\text { Nilai Pasar Ekuitas }}{\text { Nilai buku Utang }}$ 


\section{HASIL DAN PEMBAHASAN}

Hasil perhitungan $z$-score dengan menggunakan metode purposive sampling diperoleh 42 sampel perusahaan perdagangan yang terdiri dari 26 sampel perusahaan perdagangan besar dan 16 sampel perusahaan perdagangan eceran.

Kondisi financial distress perusahaan perdagangan besar dan eceran yang terdaftar di Bursa Efek Indonesia selama periode 2012 sampai dengan 2016 memiliki kondisi keuangan yang berbeda-beda setiap tahunnya, hasil tersebut dapat diuraikan sebagai berikut.

Tabel 1 Prediksi Kondisi Financial Distress Perusahaan Sub Subsektor Perdagangan Besar Periode 2012-2016

\begin{tabular}{|c|l|c|c|c|c|c|}
\hline No. & $\begin{array}{c}\text { Kode } \\
\text { Perusahaan }\end{array}$ & 2012 & 2013 & 2014 & 2015 & 2016 \\
\hline 1 & AIMS & S & S & S & S & S \\
\hline 2 & AKRA & S & $F D$ & $F D$ & S & S \\
\hline 3 & BMSR & $F D$ & $F D$ & $F D$ & S & $F D$ \\
\hline 4 & CLPI & S & S & S & S & S \\
\hline 5 & CMPP & B & B & B & B & B \\
\hline 6 & CNKO & S & S & $F D$ & $F D$ & B \\
\hline 7 & DSSA & S & S & S & S & S \\
\hline 8 & EPMT & S & S & S & S & S \\
\hline 9 & FISH & $F D$ & S & $F D$ & $F D$ & S \\
\hline 10 & HEXA & S & S & S & S & S \\
\hline 11 & INTA & B & B & B & B & B \\
\hline 12 & ITTG & S & S & S & S & S \\
\hline 13 & JKON & S & S & S & S & S \\
\hline 14 & KOBX & S & S & S & $F D$ & S \\
\hline 15 & KONI & S & $F D$ & $F D$ & $F D$ & B \\
\hline 16 & LTLS & $F D$ & S & S & $F D$ & $F D$ \\
\hline 17 & MICE & S & S & S & S & S \\
\hline 18 & OKAS & B & B & B & B & B \\
\hline 19 & SDPC & S & S & S & S & S \\
\hline 20 & TGKA & S & S & S & S & S \\
\hline 21 & TIRA & S & S & S & S & S \\
\hline 22 & TRIL & S & S & S & S & S \\
\hline 23 & TURI & S & S & S & S & S \\
\hline 24 & UNTR & S & S & S & S & S \\
\hline 25 & WAPO & B & B & B & B & B \\
\hline 26 & WICO & S & B & B & B & B \\
\hline
\end{tabular}

Sumber: data olahan

Dari Tabel 1 dapat diketahui bahwa pada tahun 2011 terdapat 19 perusahaan yang berada dalam kondisi sehat, 3 perusahaan berada dalam kondisi financial distress (FD) dan 4 perusahaan berada dalam kondisi bangkrut (B). Tahun 2012 terdapat 18 perusahaan berada dalam kondisi sehat (S), 3 perusahaan berada dalam kondisi financial distress dan 5 perusahaan berada dalam kondisi bangkrut. Tahun 2013 terdapat 18 perusahaan berada dalam kondisi sehat, 3 perusahaan berada dalam kondisi financial distress dan 5 perusahaan berada dalam kondisi bangkrut.

Tahun 2014 terdapat 16 perusahaan berada dalam kondisi sehat, 5 perusahaan berada dalam kondisi financial distress dan 5 perusahaan berada dalam kondisi bangkrut. Tahun 2015 terdapat 16 perusahaan berada dalam kondisi sehat, 5 perusahaan berada dalam kondisi financial distress dan 5 perusahaan berada dalam kondisi bangkrut. Tahun 2016 terdapat 16 perusahaan berada dalam kondisi sehat, 3 perusahaan berada dalam kondisi financial distress dan 7 perusahaan berada dalam kondisi bangkrut.

Hasil perhitungan Altman Z-Score PT Akbar Indo Makmur Stimec Tbk. (AIMS) tahun 2012 memiliki nilai Z-Score sebesar 5,637 dan tahun 2013 mengalami kenaikan sebesar $980 \%$ menjadi 60,920 kenaikan tersebut disebabkan turunnya nilai pasar ekuitas yang semula sebesar 23.436. 364.931 pada tahun 2012 menjadi 479.932.729 pada tahun 2013. Penurunan nilai pasar ekuitas berasal dari pelunasan utang usaha perusahaan senilai 22.282.542.524 pada tahun 2012 sehingga pada tahun 2013 perusahaan tidak memiliki utang usaha.

Tahun 2014 sampai dengan tahun 2016 terjadi perubahan secara fluktuasi terhadap nilai Z-Score PT Akbar Indo Makmur Stimec Tbk. Tahun 2014 perusahaan mengalami penurunan sebesar 99\% dari tahun 2013 menjadi 30,591 dan 2\% dari tahun 2014 menjadi 29,952 penurunan tersebut disebabkan karena bertambahnya nilai liabilitas jangka panjang perusahaan. Tahun 
2016 nilai Z-Score perusahaan mengalami peningkatan sebesar 69\% dari tahun 2015 menjadi 50,745 kenaikan ini juga disebabkan meningkatnya nilai $\mathrm{x} 4$ (rasio leverage).

Nilai Z-Score PT AKR Corporindo Tbk. (AKRA) selama periode tahun 2012-2016 mengalami kenaikan dan penurunan secara fluktuatif. Tahun 2012 nilai Z-Score perusahaan sebesar 3,381 dan tahun 2013 mengalami penurunan sebesar 36\% menjadi 2,475 dari tahun 2012. Penurunan tersebut disebabkan menurunnya nilai X1 karena bertambahnya nilai liabilitas jangka pendek sebesar Rp 1.450,9 miliar menjadi Rp 6.593,3 miliar dari Rp 5.142,2 miliar pada tahun 2012 sehingga perusahaan berada dalam kategori financial distress yang artinya perusahaan harus waspada dan menuntut manajemen sebagai penanggung jawab untuk memperbaiki kinerja perusahaan agar tidak mengalami kebangkrutan.

Tahun 2014 nilai Z-Score perusahaan mengalami kenaikan sebesar 4\% menjadi 2,581 dan tahun 2015 mengalami peningkatan sebesar 52\% menjadi 3,926 kenaikan tersebut dipengaruhi oleh aktiva perseroan yang meningkat dari $\mathrm{Rp}$ 14.790,1 miliar menjadi Rp 15.203,1 miliar yang disebabkan oleh adanya peningkatan persediaan tanah kawasan dalam pengembangan dari $\mathrm{Rp}$ 2.182,8 miliar menjadi Rp 3.017,4 miliar hal tersebut menunjukkan bahwa kinerja keuangan perusahaan selama periode 2014-2015 dapat dinilai cukup baik. Tahun 2016 nilai Z-Score perusahaan mengalami penurunan sebesar $10 \%$ menjadi 3,577 meskipun mengalami penurunan namun kondisi perusahaan masih dalam kategori sehat, dilihat dari nilai Z-Score yang lebih dari 2,60 .

PT Bintang Mitra Semestaraya Tbk. (B MSR) selama periode tahun 2012-2016 mengalami kenaikan dan penurunan nilai Z-Score secara fluktuasi. Pada tahun 2012 nilai Z-Score perusahaan sebesar 1,147 di mana perusahaan berada dalam kategori financial distress hal tersebut disebabkan karena perusahaan membukukan kerugian bersih konsolidasi sebesar $\mathrm{Rp}$ 29.167 juta, meningkat sebesar Rp 22.004 juta atau sebesar $307 \%$ dibandingkan pada tahun 2011 yang mencatat kerugian bersih sebesar Rp 7.163 juta. Pada tahun 2013 sampai dengan tahun 2015 nilai Z-Score Perusahaan mengalami kenaikan secara berturut-turut yaitu mengalami kenaikan sebesar 54\% di tahun 2013 menjadi 1,766 yang disebabkan peningkatan pada pendapatan perusahaan dari aktivitas sebagai distributor yang mencapai Rp 2.189.185 juta meningkat sebesar Rp 120.348 juta dibanding pendapatan di tahun 2012. Tahun 2014 mengalami kenaikan sebesar 24\% dari tahun 2013 menjadi 2,194 yang berasal dari kenaikan nilai X1 (rasio likuiditas) yang diukur dengan perbandingan modal kerja terhadap total aktiva.

Tingkat likuiditas Perusahaan pada tanggal 31 Desember 2014 adalah sebesar 149,50\% dan berada dalam posisi baik. Rasio Lancar Perusahaan mencerminkan kemampuan Perusahaan dalam memenuhi kewajiban jangka pendeknya yang merupakan komponen terbesar dalam akun kewajiban Perusahaan. Tahun 2015 mengalami kenaikan sebesar 24\% dari tahun 2014 menjadi 2,711 sehingga perusahaan berada dalam kategori sehat. Kenaikan pada tahun 2015 disebabkan oleh meningkatnya rasio X1 (rasio likuiditas) akibat menurunnya jumlah ekuitas bersih perusahaan yang pada tahun 2014 sebesar Rp 183.429 juta menjadi Rp 167.617 juta akibat selisih kurs dan penurunan goodwill pada entitas anak. Tahun 2016 mengalami penurunan sebesar 43\% dari tahun 2015 menjadi 1,895.

Penurunan ini berasal dari menurunnya jumlah aset konsolidasi Perusahaan pada tanggal 31 Desember 2016 yang tercatat sebesar Rp 498.512 
juta sedangkan jumlah aset konsolidasi pada tahun 2015 tercatat sebesar Rp 530.132 juta, mengalami penurunan sebesar Rp 31.620 juta. Aset lancar perusahaan juga mengalami penurunan sebesar Rp 28.510 juta disebabkan oleh penurunan kas dan piutang usaha pihak ketiga selain itu, jumlah kewajiban lancar perusahaan naik sebesar Rp 34.995 juta karena peningkatan utang usaha pihak ketiga, uang muka dan jaminan, utang lain-lain, dan bagian utang jangka panjang yang jatuh tempo dalam satu tahun sehingga menyebabkan rasio X1 perusahaan menurun dan perusahaan berada dalam kondisi financial distress.

PT Colorpak Indonesia Tbk. (CLPI) nilai Z-Score selama periode 2012 sampai dengan 2016 mengalami kenaikan dan penurunan nilai Z-Score secara fluktuasi. Pada tahun 2012 memiliki nilai Z-Score sebesar 5,674 dan tahun 2013 mengalami penurunan sebesar $4 \%$ dari tahun 2012 menjadi 5,139 karena perusahaan membukukan laba kotor sebesar USD 9,3 juta, laba usaha sebesar USD 4,3 juta dan laba bersih sebesar USD 1,9 juta.

Penurunan laba kotor perusahaan disebabkan peningkatan pada beban pokok penjualan akibat kenaikan biaya bahan baku. Margin laba kotor perusahaan tahun 2013 adalah sebesar $13,1 \%$ mengalami penurunan sebesar 15,7\% dibandingkan tahun 2012, dengan margin laba usaha sebesar 6,0\% dan margin laba bersih sebesar $2,7 \%$ yang masing-masing mengalami penurunan $27,5 \%$ dan $47,8 \%$ dibandingkan pencapaian pada tahun 2012. Tahun 2014 mengalami kenaikan sebesar 41\% dari tahun 2013 menjadi 7,269 peningkatan ini disebabkan total aktiva perusahaan di tahun 2014 menurun sebesar $12.6 \%$ menjadi USD 42.8 juta terutama dikarenakan penurunan pada aktiva lancar sebesar $19.6 \%$ dibandingkan tahun sebelumnya.
Penurunan aktiva lancar perusahaan ini diikuti dengan penurunan kewajiban lancar sebesar 55\%. Peningkatan Ekuitas perusahaan sebesar $19.7 \%$ menjadi USD 25,5 juta yang berasal dari laba bersih perusahaan. Tahun 2015 mengalami kenaikan sebesar 21\% dari tahun 2014 menjadi 8,803 berasal dari total aktiva perusahaan di tahun 2015 menurun sebesar 7.7\% menjadi USD 39.4 juta dibanding tahun 2014 sebesar USD 42.7 juta. Penurunan terutama terjadi pada aktiva lancar sebesar $8.7 \%$ dibanding tahun sebelumnya. Penurunan aktiva lancar perusahaan diikuti dengan penurunan kewajiban lancar sebesar 32\%. Peningkatan Ekuitas perusahaan sebesar 6.1\% menjadi USD 27,4 juta yang berasal dari laba bersih perusahaan. Tahun 2016 mengalami kenaikan sebesar 18\% dari tahun 2015 menjadi 10,416 sehingga perusahaan berada dalam kondisi sehat.

PT Rimau Multi Putra Pratama Tbk. (CMPP) selama tahun 2012-2016 memiliki nilai Z-Score negatif. Tahun 2012 memiliki nilai ZScore sebesar $(-0,054)$ tahun 2013 mengalami penurunan sebesar 429\% dari tahun 2012 menjadi $(-0,284)$ karena total aset perusahaan per 31 Desember 2013 sebesar Rp 59,997 Miliar, menurun sebesar Rp 8,6 Miliar dibandingkan dengan total asset per 31 Desember 2012. Tahun 2014 mengalami penurunan sebesar 335\% dari tahun 2013 menjadi $(-1,237)$ disebabkan pendapatan Perseroan selama tahun 2014 sebesar Rp 91,21 miliar turun 14\% dari pendapatan tahun 2013, karena penurunan pasar global terutama di segmen pertambangan dan energi.

Laba bruto per 31 Desember 2014 sebesar Rp 15,889 juta, sedangkan laba bruto per 31 Desember 2013 sebesar Rp 798 juta, sebagai akibat dari akuisisi PT Rimau Shipping oleh Perseroan. Laba bersih tercatat per 31 Desember 2014 sebesar Rp 7,884 juta dan laba bersih per 
31 Desember 2013 adalah sebesar Rp 542 juta, sebagai akibat dari kontribusi pendapatan PT Rimau Shipping yang telah terkonsolidasi ke dalam Perseroan. Tahun 2015 mengalami kenaikan sebesar 9\% dari tahun 2015 menjadi (-1.127) dan tahun 2016 mengalami kenaikan sebesar 182\% dari tahun 2015 menjadi $(-0,399)$ yang berasal dari kenaikan rasio likuiditas X1 akibat adanya peningkatan pada utang lancar secara khusus berkaitan dengan sektor perdagangan batu bara melalui anak perusahaan yang bernama PT Multi Mekar Lestari. Selama periode tahun 2012 sampai dengan periode 2016 secara laporan keuangan perusahaan PT Rimau Multi Putra Pratama Tbk. (CMPP) memiliki kecenderungan berada dalam kondisi bangkrut.

PT Eksploitasi Energi Indonesia Tbk. (CNKO) pada periode tahun 2012 memperoleh nilai Z-Score sebesar 4,560 tahun 2013 mengalami kenaikan sebesar 7\% menjadi 4,892 kenaikan tersebut disebabkan jumlah aset yang meningkat sebesar 19,2\% menjadi Rp 5.516,1 miliar di tahun 2013 dari Rp 4.628, 2 miliar di tahun 2012 yang berasal dari peningkatan aset lancar piutang usaha sebesar $72,6 \%$ menjadi Rp 663,2 miliar dari Rp 384,2 miliar dari penjualan batu bara ke pelanggan non-PLN.

Pada tahun 2014 sampai dengan 2016 mengalami penurunan secara berturut-turut. Tahun 2014 mengalami penurunan sebesar 106\% dari tahun 2013 sehingga nilai Z-Score yang diperoleh menjadi 2,375. Penyebab dari turunnya nilai $Z$ Score di tahun 2014 yang membuat perusahaan berada dalam kategori financial distress adalah pendapatan usaha yang diperoleh oleh PT Eksploitasi Energi Indonesia Tbk. sebesar Rp 993,4 miliar pada tahun 2014, menurun 39,6\% dari tahun 2013 yang sebesar Rp 1.643,6 miliar.

Penurunan ini terutama disebabkan oleh berkurangnya penjualan batu bara sebesar
41,4\% menjadi Rp 830,2 miliar, di tengah kondisi pasar yang masih kurang kondusif. Akibatnya, lini usaha pelabuhan dan sewa kapal yang merupakan industri pendukung batu bara turut terkena dampaknya, di mana pendapatan masingmasing berkurang $35,5 \%$ dan 22,4\% menjadi Rp 69,5 miliar dan Rp 36,4 miliar. Kinerja bisnis pembangkit juga turun $21,6 \%$ menjadi $\mathrm{Rp}$ 57,3 miliar, menyusul terjadinya kerusakan di PLTU Pangkalan Bun. Beban usaha perusahaan pada tahun 2014 meningkat 5\% dari tahun 2013 sehingga perusahaan mengalami kerugian sebesar Rp 28,8 miliar pada tahun 2014.

Kerugian yang dialami perusahaan PT Eksploitasi Energi Indonesia Tbk. pada tahun 2014 mengakibatkan perusahaan tidak mampu membayar utang jangka pendek perusahaan yang telah jatuh tempo serta pajak perusahaan. Pada tahun 2015 nilai Z-Score perusahaan kembali mengalami penurunan sebesar 98\% menjadi 1.195 disebabkan PT Eksploitasi Energi Indonesia Tbk. mencatatkan rugi kotor sebesar Rp 42,0 miliar. Rugi ini disebabkan karena adanya kenaikan beban pokok penjualan sebesar 35,6\% menjadi Rp 1.154,6 miliar dari Rp 851,7 miliar di tahun 2014 yang terutama berasal dari biaya pengangkutan, sejalan dengan bertambahnya volume penjualan batubara ditambah dengan adanya cadangan persediaan usang dan kerugian penurunan nilai. Tahun 2016 mengalami penurunan secara drastis yaitu sebesar $424 \%$ menjadi 0,228 .

Penurunan pada tahun 2016 disebabkan Jumlah liabilitas pada tahun 2016 adalah sebesar Rp 3.265,7 miliar, naik 4,7\% dari Rp 3.110 miliar dari tahun sebelumnya. Liabilitas jangka pendek bertambah dari Rp 2.470,1 miliar menjadi Rp 2.644,8 miliar atau naik 6,6\% hal ini terutama disebabkan karena bertambahnya utang usaha kepada pihak ketiga dari Rp 636,0 miliar 
menjadi Rp 817,0 miliar serta kenaikan jumlah liabilitas keuangan lainnya dari Rp 541,0 miliar menjadi Rp 782,3 miliar dan menyebabkan perusahaan berada dalam kondisi bangkrut.

Secara keseluruhan perusahaan perdagangan besar yang mengalami kecenderungan berada dalam kondisi financial distress adalah PT Bintang Mitra Semestaraya Tbk. (BMSR), PT Kobexindo Tractors Tbk. (KOBX), PT Perdana Bangun Pusaka Tbk. (KONI) PT Lautan Luas Tbk. (LTLS). Sedangkan perusahaan yang memiliki kecenderungan untuk bangkrut secara laporan keuangan dengan menggunakan metode Altman Z-Score adalah PT Rimau Multi Putra Pratama Tbk. (CMPP), PT Intaco Penta Tbk. (INTA), PT Ancora Indonesia Resources Tbk. (OKAS), PT Wahan Prontural Tbk. (WAPO) dan PT Wicaksana Overcheas International Tbk. (WICO).

Tabel 2 Prediksi Kondisi Financial Distress Perusahaan Sub-Sektor Perdagangan Eceran Periode 2012-2016

\begin{tabular}{|c|l|c|c|c|c|c|}
\hline No. & $\begin{array}{c}\text { Kode } \\
\text { Perusahaan }\end{array}$ & 2012 & 2013 & 2014 & 2015 & 2016 \\
\hline 1 & ACES & S & S & S & S & S \\
\hline 2 & AMRT & S & S & S & S & B \\
\hline 3 & CENT & S & S & FD & S & S \\
\hline 4 & CSAP & S & S & S & S & S \\
\hline 5 & ERAA & S & S & S & S & S \\
\hline 6 & GOLD & S & S & S & S & FD \\
\hline 7 & HERO & S & S & S & S & S \\
\hline 8 & KOIN & S & S & S & S & S \\
\hline 9 & LPPF & S & S & S & S & S \\
\hline 10 & MAPI & S & S & S & S & S \\
\hline 11 & MIDI & S & S & S & S & S \\
\hline 12 & MPPA & S & S & S & S & $F D$ \\
\hline 13 & RALS & S & S & S & S & S \\
\hline 14 & RANC & S & S & S & S & S \\
\hline 15 & RIMO & B & B & B & B & B \\
\hline 16 & SONA & S & S & S & S & S \\
\hline
\end{tabular}

(Sumber: data olahan)

Dari Tabel 2 pada perusahaan sub-sektor perdagangan eceran dapat diketahui bahwa pada tahun 2011 terdapat 15 perusahaan berada dalam kondisi sehat, 0 perusahaan berada dalam kondisi financial distress dan 1 perusahaan berada dalam kondisi bangkrut. Tahun 2013 terdapat 15 perusahaan berada dalam kondisi sehat, 0 perusahaan berada dalam kondisi financial distress dan 1 perusahaan berada dalam kondisi bangkrut. Tahun 2014 terdapat 14 perusahaan berada dalam kondisi sehat, 1 perusahaan berada dalam kondisi financial distress dan 1 perusahaan berada dalam kondisi bangkrut. Tahun 2015 terdapat 15 perusahaan berada dalam kondisi sehat, 0 perusahaan berada dalam kondisi $f i$ nancial distress dan 1 perusahaan berada dalam kondisi bangkrut. Tahun 2012 terdapat 12 perusahaan berada dalam kondisi sehat, 2 perusahaan berada dalam kondisi financial distress dan 2 perusahaan berada dalam kondisi bangkrut.

Nilai Z-Score Ace Hardware Indonesia Tbk. (ACES) selama periode tahun 2012 sampai dengan 2016 mengalami peningkatan dan penurunan secara fluktuatif. Pada tahun 2012 memperoleh nilai Z-Score sebesar 19,243 yang mengidentifikasi bahwa perusahaan berada dalam kondisi sehat. Tahun 2013 nilai Z-Score yang diperoleh perusahaan mengalami penurunan sebesar 36\% dari tahun 2012 menjadi 14,113. Pada tahun 2013 perusahaan melanjutkan untuk melakukan ekspansi serta meningkatkan kinerja dan penampilan gerai agar lebih menarik, hal tersebut menyebabkan jumlah liabilitas perusahaan yang berasal dari pos utang usaha meningkat sebesar 301,6\% dari Rp 48,7 miliar menjadi Rp 194,5 miliar. Akun ekuitas perusahaan mengalami peningkatan sebesar 15\% dari Rp 1.915 miliar menjadi Rp 1.618 miliar yang berasal dari peningkatan laba bersih tahun berjalan karena dukungan gerai baru yang dibuka pada tahun 2012 dan 2013. Peningkatan nilai liabilitas yang cukup signifikan tersebut menyebabkan nilai rasio leverage (X4) menurun karena nilai liabilias perusahaan lebih besar dari nilai ekuitasnya. 
Tahun 2014 nilai Z-Score perusahaan mengalami peningkatan sebesar $15 \%$ menjadi 15,170 yang disebabkan oleh peningkatan pada laba kotor perusahaan sebesar $13 \%$ dan laba bersih meningkat sebesar 9\% karena meningkatnya penjualan di tahun 2014 berkat kontribusi dari gerai baru yang dibuka tahun 2013 dan 2014 di beberapa kota besar di Indonesia. Tahun 2015 mengalami peningkatan tipis yaitu sebesar $0,3 \%$ sehingga nilai Z-Score-nya menjadi 15,220. Tahun 2016 mengalami peningkatan sebesar $1 \%$ dari tahun 2015 sehingga nilai $Z$-Score perusahaan menjadi 15,426 laba kotor perusahaan sebesar 4\% di tahun 2016 serta pendapatan usaha yang meningkat sebesar 14\% sehingga memengaruhi rasio profitabilitas laba di tahan terhadap total aktiva (X2) dan rasio leverage nilai pasar ekuitas terhadap nilai buku liabilitas (X4).

Sumber Alfaria Trijaya Tbk. (AMRT) selama periode tahun 2012 sampai dengan 2016 mengalami kenaikan dan penurunan nilai Z-Score secara fluktuatif. Tahun nilai $Z$-Score yang diperoleh perusahaan sebesar 4,453 dan mengalami penurunan sebesar $12 \%$ sehingga nilai -Z-Score perusahaan menjadi 3,949. Penurunan nilai $-Z$ Score di tahun 2013 disebabkan oleh meningkatnya jumlah liabilitas perusahaan terutama yang berasal dari liabilitas jangka pendek yaitu utang bank jangka pendek konsolidasian meningkat sebesar 110,39\% dari Rp 0,9 triliun menjadi Rp 1,9 triliun yang sejalan dengan penambahan gerai dan ekspansi gerai di luar Pulau Jawa. Peningkatan liabilitas tersebut menyebabkan nilai rasio likuiditas perusahaan menjadi minus karena besarnya jumlah liabilitas perusahaan yang melebihi aktiva lancar perusahaan. Tahun 2014 nilai Z-Score perusahaan mengalami peningkatan sebesar 3\% yang berasal dari peningkatan aktiva lancar perusahaan terutama pos persediaan yang meningkat sebesar $44 \%$ menjadi Rp 4,82 triliun sejalan dengan penambahan gerai dan ekaspansi gerai ke luar pulau Jawa. Tahun 2015 nilai Z-Score yang diperoleh perusahaan meningkat sebesar 31\% dari tahun 2014 menjadi 5,350. Peningkatan di tahun 2015 disebabkan oleh meningkatnya aset lancar perusahaan yang berasal dari persediaan di mana pada tahun 2015 perusahaan membuka 1 gudang baru di Batam untuk menjamin pasokan wilayah tersebut.

Tahun 2016 nilai Z-Score perusahaan kembali mengalami penurunan sebesar $27 \%$ dari tahun 2015 menjadi 4,187 yang disebabkan oleh peningkatan Aktiva Tetap perusahaan karena penambahan gudang dan kantor cabang perusahaan untuk menunjang penambahan jumlah gerai. Nilai liabilitas perusahaan pada tahun 2016 meningkat sebesar 37\% dibandingkan dengan tahun sebelumnya yang sebesar Rp 10.345 miliar menjadi Rp 14.179 miliar di tahun 2016. Peningkatan nilai liabilitas tersebut terutama disebabkan oleh meningkatnya keperluan untuk pembayaran sewa gerai, pembangunan gudang, kantor cabang, maupun penambahan modal kerja untuk ekspansi usaha.

Centrama Telekomunikasi Indonesia Tbk. pada tahun 2012 memperoleh nilai Z-Score sebesar 8,305. Tahun 2013 meningkat tipis yaitu sebesar 0,3\% menjadi 8,236. Pada tahun 2013 nilai Aktiva perusahaan meningkat sangat signifikan yaitu sebesar 675\% dari tahun 2012 menjadi Rp 667,35 miliar yang berasal dari akuisisi PT Retower Asia sebesar Rp 438,41 miliar.

Ekuitas perusahaan pada tahun 2013 meningkat sebesar $785 \%$ yang terutama disebabkan oleh peningkatan modal dasar serta penanaman modal ditempatkan dan disetor melalui penawaran umum terbatas (PUT) I sebesar Rp 684,95 miliar. Tahun 2014 nilai Z-Score perusahaan menurun secara signifikan sebesar $242 \%$ se- 
hingga menjadi 2,402. Penurunan di tahun 2014 disebabkan oleh kenaikan liabilitas jangka panjang bertambah sebesar 136,46\% atau sebesar Rp 97,50 miliar dibandingkan tahun 2013 yang tercatat sebesar Rp 71,4 miliar selain itu ekuitas perusahaan mengalami penurunan atas pencatatan Saldo rugi tahun 2014 yang belum ditentukan penggunaannya bertambah sebesar Rp 43.66 miliar akibat dari bertambahnya rugi dari tahun berjalan dari operasi yang dilanjutkan sebesar Rp 21,59 miliar dan berkurangnya rugi dari operasi yang dihentikan sebesar Rp 9,32 miliar.

Tahun 2015 perusahaan memperbaiki kinerja usahanya sehingga nilai Z-Score yang diperoleh meningkat sebesar 178\% menjadi 6,681. Peningkatan tersebut berasal dari Total Aktiva tercatat pada akhir tahun 2015 adalah sebesar Rp 1,29 triliun, naik sebesar Rp 365,84 miliar dibandingkan dengan tahun 2014 sebesar Rp 927,17 miliar. Kenaikan total aktiva ini terjadi karena bertambahnya aktiva lancar sebesar Rp 309,09 miliar atau meningkat $341,49 \%$ dan aktiva tidak lancar meningkat 6,78\% atau bertambah sebesar Rp 56,76 miliar. Peningkatan nilai aktiva lancar disebabkan karena adanya pencairan dana Right Issue II di tahun 2015 dan kenaikan piutang usaha sebesar Rp 9,53 miliar seiring dengan bertambahnya tenant di perusahaan anak. Tahun 2016 nilai Z-Score perusahaan kembali menurun sebesar 41\% menjadi 4,726 karena Jumlah liabilitas jangka pendek pada 31 Desember 2016 adalah sebesar Rp 149,01 miliar, naik 74,24\% atau sebesar Rp 63,49 miliar dibandingkan tahun 2015 yang tercatat sebesar Rp 85,52 miliar hal ini disebabkan terutama karena naiknya utang usaha pihak ketiga sebesar Rp 63,40 miliar atau naik 219,94\% di mana sebesar Rp 56,70 miliar merupakan transaksi pembelian Menara dari PT Tritunggal Putera Perkasa dan PT Centralindo tower sebanyak total 97 menara, selain itu utang lain-lain naik Rp 10,37 miliar atau 939,90\%. Selama periode tahun 2012 sampai dengan 2016 Centrama Telekomunikasi Indonesia Tbk. memiliki kecenderungan berada dalam kondisi sehat walaupun perhitungan nilai rasio perusahaan mengalami kenaikan dan penurunan secara fluktuatif namun tetap mampu mempertahankan kinerjanya.

Catur Sentosa Adiprana Tbk. pada tahun 2012 memperoleh nilai Z-Score sebesar 2,785. Tahun 2013 nilai Z-Score perusahaan menurun tipis yaitu sebesar $1 \%$ menjadi 2,757. Tahun 2014 mengalami peningkatan sebesar 15\% yang berasal dari aktiva lancar mengalami peningkatan sebesar Rp 276 miliar dari Rp 2,3 triliun pada akhir tahun 2013 menjadi Rp 2,5 triliun pada akhir tahun 2014 kenaikan tersebut mencerminkan bahwa pertumbuhan penjualan dan usaha perseroan di tahun 2014. Tahun 2015 mengalami penurunan sebesar $7 \%$ yang berasal dari liabilitas pada pos utang jangka penek perusahaan yang meningkat sebesar Rp 93 miliar. Total Aktiva Tidak Lancar pada akhir tahun 2015 tercatat sebesar Rp 916 miliar, meningkat sebesar Rp 149 miliar dari Rp 767 miliar di tahun 2014.

Kenaikan ini disebabkan oleh naiknya aset tetap - neto sebesar Rp 137 miliar dari Rp 642 miliar pada akhir tahun 2014 menjadi Rp 779 miliar pada akhir tahun 2015. Kenaikan ini diutamakan adanya pembelian aset tetap berupa tanah dan bangunan. Tahun 2016 nilai Z-Score perusahaan meningkat sebesar $21 \%$ sehingga nilainya menjadi 3,629. Peningkatan pada tahun 2016 berasal dari aktiva lancar mengalami peningkatan sebesar Rp 580 miliar dari Rp 2,5 triliun pada akhir tahun 2015 menjadi Rp 3,1 triliun pada akhir tahun 2016. Peningkatan ini terutama dikarenakan naiknya piutang usaha, dan persediaan neto masing-masing sebesar Rp 196 miliar atau 21\% dan Rp 285 miliar atau 
21\%. Kenaikan tersebut dikarenakan pertumbuhan penjualan pada tahun 2016 .

PT Erajaya Swasembada Tbk. selama periode tahun 2012 sampai dengan 2016 memperoleh nilai Z-Score yang mengalami penurunan dan peningkatan secara fluktuatif. Tahun 2102 nilai Z-Score yang diperoleh yaitu sebesar 7,284 mengalami penurunan di tahun 2013 sebesar $32 \%$ menjadi 5,497. Penurunan tersebut disebabkan oleh liabilitas perusahaan per 31 Desember 2013 adalah sebesar 2.248,29 triliun, mengalami peningkatan sebesar $71,83 \%$ dibandingkan dengan total liabilitas per 31 Desember 2012 sebesar $1.308,40$ triliun.

Kenaikan ini disebabkan oleh peningkatan utang bank jangka pendek per 31 December 2013 yang digunakan untuk operasional perseroan dan peningkatan utang dagang lancar. Tahun 2014 nilai Z-Score perusahaan turun sebesar $21 \%$ menjadi 4,518 yang disebabkan oleh meningkatnya nilai liabilitas jangka pendek yang lebih besar dibandingkan peningkatan nilai aktiva lancar. Kenaikan nilai total aktiva lancar disebabkan oleh penambahan persediaan barang dagangan terkait dengan perubahan struktur penjualan merek Samsung di PT Teletama Artha Mandiri (Entitas Anak Perseroan - TAM) menjadi Master Dealer (MD), pembukaan Erafone Megastore baru, kenaikan piutang lain-lain kepada principle, pembelian gedung dan juga disebabkan oleh estimasi klaim restitusi pajak yang akan diterima.

Semetara peningkatan liabilitas disebabkan oleh peningkatan utang bank jangka pendek per 31 Desember 2014 terkait penggunaan dana untuk operasional perseroan dan peningkatan utang dagang lancar. Tahun 2015 nilai Z-Score perusahaan menurun sebesar 30\% menjadi 3,425 yang disebabkan oleh meningkatnya liabilitas lancar perusahaan meningkat sebesar 32\% dari
Rp 2,913 triliun menjadi Rp 4,399 triliun di tahun 2015. Tahun 2016 nilai Z-Score meningkat sebesar $23 \%$ menjadi 4,245 yang berasal dari meningkatnya penjualan di tahun 2016 terutama pada segmen telepon seluler dan tablet sehingga menyebabkan laba bruto perusahaan meningkat dari $\mathrm{Rp}$ 1,5 triliun menjadi $\mathrm{Rp}$ 1,79 triliun atau tumbuh sebesar 19\%.

PT Global Teleshop Tbk. pada tahun 2012 memperoleh nilai $Z$-Score sebesar 12,615 mengidentifikasi perusahaan berada dalam kondisi sehat. Tahun 2013 nilai Z-Score mengalami penurunan sebesar $0,2 \%$ menjadi 12,593 dan tahun 2014 meningkat sebesar 15\% dari tahun 2013 menjadi 14,476. Peningkatan pada tahun 2014 berasal dari Total Ekuitas perusahaan yang meningkat dari Rp 77,758 juta menjadi Rp 80,925 juta sementara total liabilitas perusahaan menurun dari Rp 18,935 juta di tahun 2013 menjadi Rp 14,384 juta. Tahun 2015 nilai ZScore perusahaan menurun sebesar $12 \%$ menjadi 12,616 yang disebabkan oleh liabilitas perusahaan yang meningkat dari Rp 8,736 juta menjadi Rp 10,767. Pada tahun 2016 nilai Z-Score mengalami penurunan sangat signifikan yaitu sebesar $837 \%$ sehingga nilainya menjadi 1,346 .

Penurunan di tahun 2016 menyebabkan perusahaan berada dalam kondisi financial distress sehingga perusahaan patut waspada dan dengan sebaik mungkin memperbaiki kinerjanya agar tidak terjadi kebangkrutan. Penurunan nilai Z-Score di tahun 2016 disebabkan oleh meningkatnya jumlah aktiva tetap perusahaan yaitu sebesar $605,7 \%$ dari tahun sebelumnya sebesar Rp14,7 miliar menjadi sebesar Rp104,0 miliar. Peningkatan ini terutama disebabkan oleh peningkatan properti investasi, dari tidak ada di tahun sebelumnya menjadi sebesar Rp95,1 miliar di tahun 2016. Liabilitas jangka pendek perseroan di tahun 2016 ialah sebesar Rp65,6 miliar. 
Telah terjadi peningkatan sebesar 507,4\% dari tahun sebelumnya yang berada di angka Rp10,8 miliar. Peningkatan liabilitas jangka pendek tersebut terjadi akibat peningkatan utang pihak berelasi, dari tidak ada di tahun sebelumnya menjadi sebesar Rp65,6 miliar di tahun 2016. Pada 2016 perseroan mencatatkan rugi usaha sebesar Rp6,3 miliar. Besaran tersebut diperoleh dari besaran total beban yang lebih besar dibanding perolehan laba kotor. Besaran total beban pada 2016 tercatat sebesar Rp12,6 miliar, sedangkan besaran laba kotor pada 2016 tercatat Rp6,3 miliar sehingga memengaruhi seluruh nilai rasio Z-Score yang diperoleh oleh perusahaan.

Matahari Department Store Tbk. selama periode tahun 2012 sampai dengan tahun 2015 nilai Z-Score yang diperoleh perusahaan mengalami peningkatan secara berturut-turut namun, pada tahun 2016 mengalami penurunan. Tahun 2012 nilai Z-Score yang diperoleh yaitu sebesar 8,524 dan mengalami peningkatan sebesar 40\% menjadi 12,012 di tahun 2013 yang disebabkan oleh laba kotor yang disesuaikan meningkat sebesar Rp 662,6 miliar, atau 17,9\%, dari Rp 3.685,3 miliar pada tahun 2012 menjadi Rp 4.347,9 miliar pada tahun 2013.

Peningkatan ini terutama disebabkan oleh meningkatnya penjualan barang dagangan sebesar 17,2\% pada tahun 2013 dan turunnya beban pokok pendapatan sebagai persentase dari pendapatan bersih yang menyebabkan peningkatan margin laba kotor yang disesuaikan dari 33,9\% pada tahun 2012 menjadi 34,1\% pada tahun 2013. Kenaikan margin laba kotor yang disesuaikan tahun 2013 mencerminkan peningkatan dalam margin laba kotor yang disesuaikan dari penjualan ritel yang disebabkan oleh perbaikan berkelanjutan dalam program merchandise produk ritel di mana jenis produk ritel utama dipilih dan dibeli dalam jumlah besar dengan harga yang lebih menguntungkan.
Tahun 2014 mengalami peningkatan sebesar $3 \%$ dan nilai Z-Score perusahaan menjadi 12,472 dan tahun 2015 meningkat sebesar 8\% menjadi 13,553. Kenaikan Z-Score tersebut disebabkan oleh aktiva lancar perseroan yang sebagian besar terdiri dari kas, setara kas dan persediaan, meningkat 7,3\% dari tahun 2014 menjadi Rp 2.272,9 miliar pada tahun 2015. Kenaikan persediaan sejalan dengan pembukaan 11 gerai baru pada tahun 2015. Kenaikan ini juga disebabkan oleh kenaikan harga barang dagangan dan meningkatnya jumlah persediaan untuk memenuhi kenaikan target penjualan. Kewajiban lancar menurun menjadi Rp 2.439,0 miliar pada tahun 2015 dari Rp 2.518,5 miliar pada tahun 2014 sebagai dampak dari pelunasan pinjaman sindikasi di tahun 2015 sehingga menyebabkan nilai rasio (X1) mengalami peningkatan.

Tahun 2016 Z-Score perusahaan menurun sebesar 2\% menjadi 13.157 yang disebabkan oleh laba kotor perseroan meningkat $\mathrm{Rp} 540,5$ miliar atau 9,5\%, dari Rp 5.671,3 miliar pada tahun 2015 menjadi Rp 6.211,8 miliar pada tahun 2016. Laba kotor yang disesuaikan dari penjualan produk ritel meningkat 14,2\%.

Laba kotor yang disesuaikan dari penjualan konsinyasi, yang diukur dengan pendapatan bersih dari penjualan konsinyasi, meningkat sebesar 5,4\% pada tahun 2016. Aktiva lancar perseroan yang sebagian besar terdiri dari kas, setara kas, dan persediaan meningkat 30,9\% dari tahun 2015 menjadi Rp 2.974,1 miliar pada tahun 2016. Kenaikan kas dan setara kas disebabkan oleh pembayaran pinjaman bank pada akhir tahun 2015. Aktiva tidak lancar meningkat $16,6 \%$ menjadi Rp 1.884,8 miliar pada akhir tahun 2016 dengan kontribusi utama dari penambahan Aktiva tetap sebesar Rp 103,3 miliar atau meningkat $11,8 \%$ sebagai akibat dari pembukaan 9 gerai baru. 
Supra Boga Lestari Tbk. pada tahun 2012 memperoleh nilai Z-Score sebesar 6,447 dan mengalami penurunan sebesar 3\% dari tahun 2012 menjadi 6,251. Penurunan di tahun 2013 disebabkan oleh jumlah aktiva meningkat sebesar Rp 142 miliar atau 24,9\% menjadi Rp 712,1 miliar pada akhir tahun 2013, yang terutama dikarenakan dari peningkatan pada aset lancar sebesar Rp 71,5 miliar dan aset tidak lancar sebesar Rp 70,5 miliar. Aktiva lancar yang mengalami peningkatan terutama adalah persediaan sebesar Rp 65,2 miliar yang terutama merupakan kenaikan barang dagangan untuk menunjang operasional toko dan uang muka dan biaya dibayar di muka sebesar Rp 50,9 miliar. Jumlah liabilitas pada akhir tahun 2013 adalah sebesar Rp 315,0 miliar, naik sebesar Rp 104,2 miliar atau $49,4 \%$ dari tahun sebelumnya. Kenaikan ini terutama karena adanya kenaikan utang usaha untuk pembelian barang dagangan sebesar $\mathrm{Rp}$ 78,7 miliar dan penambahan utang bank jangka pendek yang diperoleh dari PT Bank Mandiri (Persero) Tbk sebesar Rp 30,0 miliar. Tahun 2014 mengalami penurunan tidak signifikan yaitu sebesar 1\% menjadi 6,143. Tahun 2015 nilai ZScore perusahaan meningkat sebesar $11 \%$ menjadi 6,976 yang berasal dari Jumlah Aktiva yang menurun sebesar rp 61,7 miliar atau 7,9\% menjadi rp 720,7 miliar pada akhir tahun 2015, yang terutama dikarenakan dari penurunan aset lancar sebesar $\mathrm{Rp}$ 12,4 miliar dan penurunan pada aset tidak lancar sebesar Rp 49,3 miliar. Tahun 2016 mengalami peningkatan sebesar 16\% menjadi 8,369 yang berasal dari Laba bruto tahun 2016 naik 8,8\% menjadi sebesar Rp 507,8 miliar dikarenakan kenaikan pendapatan bersih yang menghasilkan marjin laba kotor sebesar $24,6 \%$.

Secara keseluruhan perusahaan perdagangan besar yang mengalami kecenderungan berada dalam kondisi financial distress adalah: Centrama Telekomunikasi Indonesia Tbk. (CENT), Global Teleshop Tbk. (GOLD), dan Matahari Putra Prima Tbk. (MPPA). Sedangkan perusahaan yang memiliki kecenderungan untuk bangkrut secara laporan keuangan dengan menggunakan metode Altman Z-Score adalah Sumber Alfaria Trijaya Tbk. (AMRT) dan Rimo International Lestari Tbk. (RIMO).

\section{KESIMPULAN}

Berdasarkan hasil analisis data perusahaan perdagangan sub-sektor perdagangan besar dan eceran yang terdaftar di Bursa Efek Indonesia periode 2012 sampai dengan 2016 dapat diambil kesimpulan bahwa perusahaan perdagangan besar cenderung lebih banyak yang mengalami kondisi finansial distress dari pada perusahaan eceran. Perusahaan eceran cenderung berada dalam kondisi sehat karena selama periode tahun 2012 sampai dengan 2016 hanya terdapat tiga perusahaan saja yang berada dalam kondisi financial distress namun perusahaan tersebut berhasil memperbaiki kinerjanya sehingga berada dalam kondisi sehat di tahun 2016. Pada perusahaan perdagangan besar yang berada dalam kondisi financial distress dan berpotensi mengalami financial distress selama periode tahun 2012 sampai dengan tahun 2016 adalah PT Bintang Mitra Semestaraya Tbk. (BMSR), PT Kobexindo Tractors Tbk. (KOBX), PT Perdana Bangun Pusaka Tbk. (KONI) PT Lautan Luas Tbk. (LTLS).

Hasil penelitian menggunakan metode Altman Z-Score pada perusahaan perdagangan besar dan eceran menunjukkan bahwa selama periode tahun 2012 sampai dengan 2016 menurut laporan keuangan terdapat beberapa perusahaan yang mengalami kebangkrutan pada masa yang akan datang, namun hal tersebut dapat dipatahkan 
dengan bukti bahwa pada saat ini perusahaanperusahaan tersebut masih terdaftar di Bursa Efek Indonesia pada periode ini.

Oleh karena itu, metode ini hanya dapat dipakai sebagai alat pendeteksi dini untuk mengantisipasi perusahaan yang berada dalam kondisi financial distress agar dapat meningkatkan kinerja manajemennya dan bukan sebagai alat perhitungan yang akurat dan pasti. Kebangkrutan suatu perusahaan tidak hanya dilihat dari sisi keuangan atau internal saja melainkan banyak faktor lain yang menjadi penyebab kebangkrutan perusahaan seperti faktor eksternal perusahaan.

\section{DAFTAR RUJUKAN}

Andriawan, Nur Fadli \& Dantje Salean, (2016). Analisis Metode Altman Z- Score Sebagai Alat Prediksi Kebangkrutan dan Pengaruhnya Terhadap Harga Saham pada Perusahaan Farmasi yang Terdaftar di Bursa Efek Indonesia. Jurnal Ekonomi Akuntansi, 1.01. Arini, Sopiyah \& Triyonowati. (2013). Analisis Altman Z-Score untuk Memprediksi Kebangkrutan pada Perusahaan Farmasi di Indinesia. Jurnal Ilmu dan Riset Manajemen, Vol. 2, No. 11.

Boby, M. Rasuli \& Nur Azlina. (2014). Analisis Rasio Keuangan Metode Z-Score (Altman) dan Camel untuk Memprediksi Potensi Kebangkrutan pada Perusahaan Perbankan yang Listing di BEI. Jom Fekon, Vol. 1, No. 2.

Brahmana, Rayenda K. (2007). Identifying Financial Distress Condition in Indonesia Manufacture Industry. Birmingham Business School, University of Birmingham United Kingdom, 1-19.

Cahyaningtyas, Icha, Untung Sriwidodo, \& Setyaningsih Sri Utami. (2016). Analisis
Financial Distress Menggunakan Model Altman Z-Score pada Perusahaan Asuransi yang Listing di Bursa Efek Indonesia Tahun 2011-2014. Jurnal Ekonomi dan Kewirausahaan, Vol. 16, No. 2.

E.Altman. (1983). Financial Ratios, Discriminant Analysis and the Prediction of Corporate Bankruptcy. Journal of accounting.

Fahmi, Irham. (2011). Analisis Laporan Keuangan. Bandung: Alfabeta.

Hadi, Syamsul \& Atika Anggraeni. (2008). Pemilihan Prediktor Delisting Terbaik (Perbandingan Antara the Zmijewski Model, the Altman Model, dan the Springate Model). Jurnal Akuntansi dan Auditing Indonesia, 12.2.

Harahap, Sofyan. (2006). Analisis Kritis atas Laporan Keuangan. Jakarta: PT Raja Grafindo Persada.

Hidayat, Muhammad Arif Wahyu Meiranto. (2014). Prediksi Financial Distress Perusahaan Manufakur di Indonesia. Diponegoro Journal of Accounting, 538-548.

Irfan, Mochamad. (2015). Analisis Financial Distress dengan Pendekatan Altman Z"Score untuk Memprediksi Kebangkrutan Perusahaan Telekomunikasi. Jurnal Ilmu \& Riset Manajemen, 3.1.

Kasmir. (2014). Analisis Laporan Keuangan. Jakarta: PT Raja Grafindo Persada.

Maina, F. G. \& M. M. Sakwa. (2017). Understanding Financial Distress among Listed Firms in Nairobi Stock Exchange: A Quantitative Approach Using The Z-Score Multi Discriminant Financial Analysis Model. Nairobi, Kenya: Jomo Kenyatta University of Agriculture and Technology.

Noviandri, Tio. (2014). Peranan Analisis Rasio Keuangan dalam Memprediksi Kondisi Financial Distress Perusahaan Sektor 
Perdagangan. Jurnal Ilmu Manajemen, Vol. 2, No. 4.

Patunrui, Katarina Intan Afni \& Sri Yati. (2017). Analisis Penilaian Financial Distress Menggunakan Model Altman (Z-Score) pada Perusahaan Farmasi yang Terdaftar di Bursa Efek Indonesia Periode 20122015. Jurnal Akuntansi, Ekonomi, dan Manajemen Bisnis, Vol. 5, No. 1.

Platt, H. D. \& M. B., Platt. (2002). Predicting Corporate Financial Distress: Reflections on Choice-Based Sample Bias. Journal of Economics and Finance, Vol. 26, No. 2.

Prihatini, Ni Made Evi Dwi \& Maria M. Ratna Sari. (2013). Prediksi Kebangkrutan dengan Model Grover, Altman Z-Score, Springgate dan Zmijewski Pada Perusahaa Food and Beverage di Bursa Efek Indonesia. E-jurnal Akuntansi, 5.2: 417-435.

Purnajaya, Komang Devi Methili \& Ni K. Lely A. Merkusiwati. (2014). Analisis Komparasi Potensi Kebangkrutan dengan Metode Z-score Altman, Springate, dan Zmijewski pada Industri Kosmetik yang Terdaftar di Bursa Efek Indonesia. E-Jurnal Akuntansi, 7.1: 48-63.

Rahayu, Fitriani, I. Wayan Suwendra, \& Ni Nyoman Yulianthini. (2016). Analisis Fi- nancial Distress dengan Menggunakan Metode Altman Z- Score, Springate, dan Zmijewski pada Perusahaan Telekomunikasi. Jurnal Jurusan Manajemen, 4.1.

Rahayu, Santi Suci \& Rina Nofiyanti. (2011). Analisis Laporan Keuangan dengan Metode Altman untuk Memprediksi Kepailitan pada Perusahaan Industri Makanan dan Minuman. Jurnal Ilmiah Ekonomi Bisnis, 15.2.

Rahmania, Meilita Fitri \& Suwardi Bambang Hermanto. (2014). Analisis Rasio Keuangan terhadap Financial Distress Perusahaan Perbankan Studi Empiris di BEI 20102012. Jurnal Ilmu \& Riset Akuntansi, Vol. 3, No. 11.

Rudianto. (2013). Akuntansi Manajemen Informasi untuk Mengambil Keputusan Strategis. Yogyakarta: Erlangga.

Sartono, Agus. (2001). Manajemen Keuangan Teori dan Aplikasi, Edisi IV. Yogyakarta: BPFE..

Yulia, Anggi \& Triyonowati (2013). Analisis Kebangkrutan Metode Altman Z-Score pada Perusahaan Rokok Go Public. Jurnal Ilmu dan Riset Manajemen, Vol. 2, No. 3. www.bps.go.id diakses pada 18 April 2017. www.idx.co.id diakses pada 2 April 2017. 